\title{
EARNINGS AND FIRM VALUE: THE MODERATING IMPACT OF LARGE DEFERRED TAXES AND LARGE ACCRUALS IN INDONESIA
}

\author{
Bambang SUTOPO ${ }^{1 *}$, Arum Kusumaningdyah ADIATI ${ }^{\circledR 2}$, Purnama SIDDI ${ }^{3}$ \\ ${ }^{1,2}$ Faculty of Economics and Business, Universitas Sebelas Maret, Surakarta, Indonesia \\ ${ }^{3}$ Faculty of Economics, Universitas Islam Batik Surakarta, Surakarta, Indonesia
}

Received 20 January 2020; accepted 13 January 2021

\begin{abstract}
Deferred tax and accruals have the characteristic of causing reported earnings to be above or below normal. Both are permitted to be used by companies in financial reporting. This study examines whether large deferred taxes and large accruals have an impact on the relationship between earnings and firm value. Using a sample that includes 1938 company-year observations for the 2007-2017 periods listed on the Indonesia Stock Exchange (IDX), this study found that large positive deferred taxes with large positive accruals had weakened the relationship between earnings and firm value. In contrast to these results, a large negative deferred tax with a large negative accrual does not have an impact on the relationship between earnings and the firm value. This finding suggests that "liberal" accounting policies that cause reported "above normal" earnings have a negative effect on the association between earnings and firm value. However, "below normal" earnings resulting from "conservative" accounting policies do not affect the association between earnings and firm value. The uniqueness of this study is the incorporation of deferred taxes with accruals with variations in the form of positive versus negative and large versus small. The findings imply that the presentation of financial information with small deferred taxes and small accruals is more beneficial for investors compared to financial information with large positive deferred taxes and large positive accruals. However, results of this study indicate that large negative deferred taxes and large negative accruals, indicating conservative accounting, are not responded differently by investors.
\end{abstract}

Keywords: earnings, firm value, Tobin's Q, deferred tax, accruals, Indonesia Stock Exchange (IDX).

JEL Classification: M41.

\section{Introduction}

Financial information is important for investors in determining the firm value. This is in line with the purpose of designing a financial reporting system that provides information that is useful for decision making by investors as one of the main users of financial information. Previous studies (e.g. Chang et al., 2013; Loh et al., 2017; Mbugua et al., 2018; Osazuwa \& Che-ahmad, 2016; Qu \& Zhang, 2015) have provided empirical evidence about the relationship between financial information specifically earnings and firm value. However, the usefulness of earnings information is influenced by the quality of the earnings. High-quality earnings information increases the usefulness of the earnings information and conversely low earnings quality decreases the usefulness of the earnings information (e.g. Callao et al., 2016; Li, 2019).
There is an interesting phenomenon about the earnings and firm value that indicate the symptoms of the problem. A company's earnings can change from one year to the next. For example, Aneka Tambang (Persero) Tbk. (ANTM) reported earnings $(\mathrm{E})$, measured by net income divided by total assets, of 0.152 in 2012 and decreased to 0.0187 in 2013. This change was followed by changes in firm value, measured by Tobin's Q, amounting to 0.968 in the year 2012 and dropped to 0.890 in 2013. The decline in the value of the company is relatively small compared to the decline in earnings. Besides, in 2012 ANTM reported deferred taxes (DTTA) and accruals (ACCTA) included in the large DTTA and ACCTA group, while in 2013 ANTM reported deferred taxes (DTTA) and accruals (ACCTA) included in the group of small DTTA and ACCTA. However, that phenomenon is only a case. The question is whether, on average, DTTA and ACCTA have an impact on the association between earnings (E) and firm value $(\mathrm{Q})$ ?

${ }^{*}$ Corresponding author. E-mail: bbsutopo@yahoo.com 
Deferred tax and accruals can be used as indicators of earnings information quality. Deferred tax shows the difference between accounting tax and tax determined by the tax authorities. Deferred tax can be used to detect earnings quality (Kasipillai \& Mahenthiran, 2013; Phillips \& Pincus, 2003; Samara, 2014). Accruals showing non-cash income and/or costs also have the potential to reduce earnings quality. Large accruals decrease earnings persistence (Lewellen \& Resutek, 2019; Sloan, 1996). This study examines the relationship between earnings and firm value when deferred tax and accruals are large. The findings of this study show that the relationship between earnings and firm value decreases when positive deferred taxes accompanied by positive accruals are large. However, a large negative deferred tax that is accompanied by a large negative accrual does not have an impact on the relationship between earnings and firm value.

\section{Literature review and hypotheses - the impact of large deferred tax and accruals on the relationship between earnings and firm value}

Firm value reflects the value of a business. Following previous studies (e.g. Buchanan et al., 2018; Khaoula \& Moez, 2019; Lee, 2019; Ni et al., 2019) the firm value is proxied by Tobin's Q. Earnings which is revenues minus expenses is measured by net income divided by total assets (Wang, 2019). Similar to previous studies (Chen \& Gong, 2019; Lewellen \& Resutek, 2019; Moreira et al., 2019), accruals in this study are non-cash profits with a proxy of the difference between earnings and operating cash flow. The study of deferred tax can use data presented in the balance sheet (e.g. Bauman \& Shaw, 2016; Hanlon et al., 2014; Kasipillai \& Mahenthiran, 2013; Samara, 2014) or presented in the income statement, which is often used as a component for measurement book-tax differences (for example Blaylock et al., 2012; Hanlon \& Shevlin, 2005). This study uses deferred tax that is presented in the income statement because the deferred tax is directly related to earnings in a period, to determine its impact on the relationship between earnings and firm value. Deferred tax can be good or bad, among others, depending on the prospects for the company's performance. Because the future performance is unknown, this study uses a proxy for earnings quality that can be used in stock valuation. The earnings quality is measured by small accruals to represent relatively high earnings quality and large accruals to represent relatively low earnings quality. Deferred taxes and accruals can be positive or negative. As in the study of Blaylock et al. (2012) and Hanlon and Shevlin (2005) which separates positive book-tax differences from negative book-tax differences, deferred taxes in this study are grouped into large positive deferred taxes (with large positive accruals) and large negative deferred taxes (with large negative accruals). Each group is discussed concerning its impact on the relationship between profits and firm value as discussed in the following sub-section.

\subsection{The impact of large positive deferred taxes and large positive accruals on the association between earnings and firm value}

Positive deferred taxes add to current taxes and generate net taxes. Thus, a positive deferred tax is related to profit before tax in the income statement that is greater than taxable profit. Accruals are non-cash flow values recorded in the financial statements (Penman, 2013). Positive accruals indicate that net income is greater than operating cash flow. Large positive accruals imply the use of "liberal" accounting policies, which can have implications for reported earnings that are "above normal". Thus, both a large positive deferred tax and a large positive accrual have an impact on the decline in earnings quality. Earnings is a piece of important information for stock valuation. Forecasting-based stock valuation, among others, requires current earnings to forecast future earnings so that they can be used as a basis for stock valuation. When the quality of earnings information is low, the usefulness of earnings information in predicting future earnings will decrease. In turn, the usefulness of earnings information in stock valuations will be reduced. Previous studies (such as Akbar et al., 2011; Shan, 2015; Tang \& Firth, 2012) with various proxies show the impact of earnings quality on the value relevance of earnings for investors.

The firm value proxied by Tobin's $Q$ is the market value of equity plus the market value of debt (which is proxied by the book value of debt) and divided by the book value of total assets. In general, the firm value is the market value of total assets divided by the book value of total assets. The book value of total assets is affected by accounting policies. The total book value of assets presented based on "liberal" accounting policies (instead of "neutral") can have an impact on reported "above normal" assets. If the market value (Tobin's Q) is following the "semi-strong form efficient market" theory and the decision usefulness theory that underlies financial reporting (Scott, 2015) then the market value with "above normal" assets will be lower than the market value with "normal" assets. "Liberal" accounting policies also have the same effect on reported earnings as on assets, i.e. the impact on reported earnings "above normal". Therefore, from the perspective of and the decision usefulness theory to financial reporting (Scott, 2015) and signaling theory (Spence, 1973), we hypothesize that a large positive deferred tax (LPDT) and a large positive accrual (LPA) can be a signal of low-quality earnings information, and in turn, will weaken the relationship between earnings (E) and firm value (Q).

\subsection{The impact of large negative deferred taxes and large negative accruals on the association between earnings and firm value}

The negative deferred tax has the opposite properties to negative deferred tax. Likewise, negative accruals have properties that are reversed with positive accruals. Negative deferred tax reflects that income before tax in the 
income statement is smaller than taxable income. Concerning earnings information, negative accruals are a non-cash earnings component which causes that earnings are lower than operating cash flow. Financial reporting allows the adoption of "conservative" accounting policies that make reported earnings "below normal". Conservative accounting can be seen as a negative signal for the company's future performance because it generates abnormal ("below normal") profits. However, "conservative" accounting policies can also be seen as positive signals because of the principle of prudence in financial reporting.

Blaylock et al. (2012) show that negative book-tax differences and absolute accruals weaken the relationship between earnings and stock returns. Also, Adiati et al. (2018) found that absolute deferred taxes weaken the value relevance of earnings. Conservative accounting can increase the value relevance of accounting information, but excessive conservative accounting results in decreased value relevance (Kousenidis et al., 2009). This study aims to provide empirical evidence from the capital market in Indonesia. We hypothesize that large negative deferred taxes (LNDT) and large negative accruals (LNA) have weakened the relationship between earnings (E) and firm value $(\mathrm{Q})$.

\section{Methodology}

This research data consists of data on company financial statements listed on the Indonesia Stock Exchange (BEI) which includes earnings, deferred tax, total debt, total assets, type of industrial sector and market data which includes stock prices and market capitalization. The data source in the financial statements and market data is The Indonesia Capital Market Institute (TICMI).

The initial sample includes 5243 company-year observations from the 2007 to 2017 financial reporting period. To meet the objectives of testing the effects of moderating large deferred taxes and large accruals on the association between earnings and corporate value, we use the following sample selection criteria: (1) availability of financial data for 12 months per year, positive equity, availability of deferred tax data in the income statement, and availability of other research data. With these criteria, a final sample of 1938 observations was obtained.

To examine the impact of large deferred taxes and large accruals on the relationship between earnings and firm value, the following regression models are used. We use large deferred taxes instead of amounts of deferred taxes. This follows the study of Hanlon and Shevlin (2005) and Blaylock et al. (2012) because large and small deferred taxes can better differentiate the quality of financial information, especially earnings information. Similarly, we also use large versus small accruals to distinguish the quality of earnings information. The models are as follows.

$$
Q=\beta_{0}+\beta_{1} E+\beta_{2} L P D T \times L P A+\beta_{3} L N D T \times L N A+\varepsilon ;
$$

$$
\begin{aligned}
& Q=\beta_{0}+\beta_{1} E+\beta_{2} L P D T \times L P A+\beta_{3} L N D T \times L N A+ \\
& \beta_{4} L P D T \times L P A \times E+\beta_{5} L N D T \times L N A \times E+\varepsilon ; \\
& Q=\beta_{0}+\beta_{1} E+\beta_{2} L P D T \times L P A+\beta_{3} L N D T \times L N A+ \\
& \beta_{4} L P D T \times L P A \times E+\beta_{5} L N D T \times L N A \times E+\beta_{6} D A R+ \\
& \beta_{7} S I Z E+\beta_{n} \sum_{n=1}^{9}(S E C T O R)+\varepsilon,
\end{aligned}
$$

where

$Q$ is Tobin's $Q$ as a proxy for firm value with the formula: (market value of equity + total debt) / total assets or $(M V E+D) / T A)$. Tobin's $Q$ has been widely used in previous studies, such as Adegboye et al. (2019); Li (2019); Martins and Lopes (2016); Nazir and Afza (2018); Ni et al. (2019); Wang (2019).

$E$ (earnings) is profit for the period divided total asset. This measure shows the company's performance as measured by accounting indicators (Adegboye et al., 2019).

$L P D T \times L P A$ is a dummy variable with a value of 1 if the company has a large positive deferred tax (above the median) with a large positive accrual (above the median) in the income statement divided by total assets, and with a value of 0 if otherwise. The use of the median for grouping observations in the sample follows previous studies (e.g. Eyring \& Narayanan, 2018; Farooq et al., 2020; Hossain \& Nguyen, 2016; Prabowo et al., 2018). The use of LPDT is similar to Blaylock et al. (2012) in measuring LPBTD. Kantšukov and Sander (2018) suggested that distributed profit taxation (DPT) is better (in terms of fundamental equity value) compared to traditional / classical profit taxation (TPT). This study breaks down tax costs into current taxes and deferred taxes, and subsequently deferred taxes are grouped into large deferred taxes (LDT), either positive or negative, and small deferred taxes (SDT). Likewise, LPA is measured in the same way as LPDT. Accrual accounting can meet the need for information quality for decision making purposes (Tikk, 2010).

$L P D T \times L P A \times E$ is an interaction variable between $L P D T \times L P A$ and $E$.

$L N D T \times L N A$ is a dummy variable with a value of 1 if the company has a large negative deferred tax (below the median) with a large negative accrual (below the median) in the income statement divided by total assets, and with a value of 0 if otherwise.

$L N D T \times L N A \times E$ is an interaction variable between $L N D T \times L N A$ and $E$.

$D A R$ is the ratio of debt to total assets which shows the proportion of corporate debt financing.

SIZE is the size of the company measured by the logarithm of market capitalization.

SECTOR 1 - SECTOR 9 are industrial sector dummy variables with a value of 1 for the related sector and 0 for other sectors.

DAR, SIZE, and SECTOR 1 - SECTOR 9 are control variables. 


\section{Empirical results and discussion}

\subsection{Correlations}

Table 1 presents the correlations between the variables in the regression model. The correlation coefficient between firm value $(Q)$ and earnings $(E)$ is 0.412 , significant at the 1 percent level. These results are consistent with the positive association between earnings and firm value. Further results regarding the relationship between the two variables are presented in Table 3. The debt to total assets ratio $(D A R)$ has a negative coefficient $(-0.131)$ significant at the 1 percent level. These results indicate that DAR as a control variable plays a role in explaining the variation of $Q$. Firm size (SIZE) which is the natural logarithm of market capitalization (MARKETCAP) is positively correlated with $\mathrm{Q}$, meaning that $S I Z E$ also plays a role in explaining $Q$.

The correlation between earnings $(E)$ and the control variable $D A R$ is negative $(-0.327)$ significant at the 1 percent level, while the correlation between E and SIZE is positive $(0.266)$ which is also significant at the 1 percent level. However, the correlation coefficients are smaller than the correlation coefficients between $E$ and $Q$. This also applies to the correlation between DAR and SIZE. These results indicate that there is no multicollinearity problem in the regression. Industrial sector control variables (S1-S8) are dummy variables and are not included in the correlation analysis.

Table 1. Correlations

\begin{tabular}{|l|c|c|c|c|c|}
\hline \multicolumn{1}{|c|}{ VARIABLE } & $Q$ & $E$ & DAR & $\begin{array}{c}\text { MAR- } \\
\text { KETCAP }\end{array}$ & SIZE \\
\hline$Q$ & 1 & & & & \\
\hline$E$ & $.412^{\star *}$ & 1 & & & \\
\hline DAR & $-.131^{\star *}$ & $-.327^{\star *}$ & 1 & & \\
\hline MARKETCAP & $.190^{\star *}$ & $.142^{\star *}$ & $.099^{\star *}$ & 1 & \\
\hline SIZE & $.406^{* *}$ & $.266^{\star *}$ & $.051^{\star}$ & $.477^{\star *}$ & 1 \\
\hline
\end{tabular}

Notes: ${ }^{* \star}$ Correlation is significant at the 0.01 level (2-tailed).

* Correlation is significant at the 0.05 level (2-tailed).

\subsection{Descriptive statistics}

Descriptive statistics are presented in Table 1. Panel A presents descriptive statistics for the full sample which includes 1938 observations. The mean value of Q (firm value) is 1.324 with a range of values from 19.858 to 0.018 , while the mean value of $\mathrm{E}$ (earnings) is 0.059 with a range of values between 1.478 and 0.0000181 (rounded to 0.000 ). The average debt financing (DAR) is 0.511 , with the highest value of 0.988 and the lowest value of 0.004 . The size of the company using market capitalization in trillion Rupiahs (IDR) has a mean value of IDR7,019 trillion with a range of values between IDR447,552 trillion and IDR0,000 trillion. SIZE is a firm size using the log value of market capitalization.
A comparison between descriptive statistics in Panel B (Subsample of Large Positive Deferred Tax accompanied by Large Positive Accruals) and Panel C (Subsample of Small Deferred Tax accompanied by Small Accruals) shows that the mean value of earnings (E) in Panel B (0.077) is relatively greater than the mean earnings in Panel $C$ (0.054). However, the mean value of the firm value $(Q)$ in Panel B (1.318) is lower than that in Panel C (1.326). These results can imply that the relationship between earnings and firm value for companies with large positive deferred taxes and large positive accruals is weaker than that for companies that do not report large positive deferred taxes with large positive accruals. Large earnings caused by accounting policies that increase reported earnings shown by large positive deferred taxes and large positive accruals tend to reduce the effect of earnings on firm value These results might imply that accounting policies that increase reported earnings are responded negatively by investors.

In contrast to the results of the comparison between descriptive statistics in Panel B and Panel C, the mean value of earnings and firm value in Panel D (Subsample of Large Negative Deferred Tax accompanied by Large Negative Accruals) is relatively greater (1.348 and 0.068, respectively) compared to that in Panel E or Subsample of Small Deferred Tax accompanied by Small Accruals (1.323 and 0.058 respectively). These results may imply that the relationship between earnings and the firm value of companies with large negative deferred taxes accompanied by large negative accruals is not weaker than that for companies that do not report large negative deferred taxes with large negative accruals. These results might imply that accounting policies that reduce reported earnings ("conservative") are not responded negatively by investors.

Descriptive statistics for control variables show that the companies in Panel B tend to have lower debt financing (DAR) and a smaller size compared to that in Panel C. Besides, companies in Panel D tend to have greater debt financing $(D A R)$ and company size (SIZE) compared to that in Panel E. These results imply that companies that report large positive deferred taxes accompanied by large positive accruals are companies that use smaller debt financing and are relatively small. On the other hand, companies that report large negative deferred tax with large negative accruals are companies that use larger debt financing and are relatively large. These companies appear to be more conservative in reporting their financial performance.

Table 2. Descriptive statistics

\begin{tabular}{|l|c|c|c|c|c|}
\hline \multicolumn{7}{|c|}{ Panel A: Full sample (1938 observations) } \\
\hline$Q$ & 1.324 & 0.993 & 19.858 & 0.018 & 1.218 \\
\hline$E$ & 0.059 & 0.038 & 1.478 & 0.000 & 0.070 \\
\hline DAR & 0.511 & 0.518 & 0.988 & 0.004 & 0.230 \\
\hline MARKETCAP & 7.019 & 0.542 & 447.552 & 0.000 & 29.088 \\
\hline SIZE & 27.069 & 27.018 & 33.735 & 18.682 & 2.317 \\
\hline \multicolumn{7}{|c|}{ Panel B: LPDT \& LPAC (376 observations) } \\
\hline Q & 1.318 & 0.982 & 12.378 & 0.125 & 1.238 \\
\hline
\end{tabular}


End of Table 2

\begin{tabular}{|c|c|c|c|c|c|}
\hline Variable & Mean & Median & $\begin{array}{l}\text { Maxi- } \\
\text { mum }\end{array}$ & $\begin{array}{l}\text { Mini- } \\
\text { mum }\end{array}$ & $\begin{array}{l}\text { Std. } \\
\text { Dev. }\end{array}$ \\
\hline$E$ & 0.077 & 0.054 & 1.478 & 0.001 & 0.102 \\
\hline$D A R$ & 0.501 & 0.511 & 0.943 & 0.006 & 0.234 \\
\hline MARKETCAP & 2.801 & 0.427 & 118.381 & 0.000 & 8.902 \\
\hline SIZE & 26.784 & 26.779 & 32.405 & 19.521 & 2.057 \\
\hline \multicolumn{6}{|c|}{ Panel C: NON-LPDT \& NON-LPAC (1562 observations) } \\
\hline$Q$ & 1.326 & 0.997 & 19.858 & 0.018 & 1.213 \\
\hline E & 0.054 & 0.035 & 0.577 & 0.000 & 0.059 \\
\hline$D A R$ & 0.513 & 0.518 & 0.988 & 0.004 & 0.229 \\
\hline MARKETCAP & 8.035 & 0.576 & 447.552 & 0.000 & 32.025 \\
\hline SIZE & 27.138 & 27.079 & 33.735 & 18.682 & 2.370 \\
\hline \multicolumn{6}{|c|}{ Panel D: LNDT \& LNAC (124 observations) } \\
\hline Q & 1.348 & 1.029 & 9.295 & 0.105 & 1.107 \\
\hline$E$ & 0.068 & 0.039 & 0.577 & 0.001 & 0.079 \\
\hline$D A R$ & 0.550 & 0.558 & 0.965 & 0.099 & 0.208 \\
\hline MARKETCAP & 13.995 & 0.433 & 312.984 & 0.000 & 49.019 \\
\hline SIZE & 26.853 & 26.795 & 33.377 & 18.912 & 2.776 \\
\hline \multicolumn{6}{|c|}{ Panel E: NON-LNDT \& NON-LNAC (1814 observations) } \\
\hline Q & 1.323 & 0.990 & 19.858 & 0.018 & 1.225 \\
\hline$E$ & 0.058 & 0.038 & 1.478 & 0.000 & 0.069 \\
\hline$D A R$ & 0.508 & 0.515 & 0.988 & 0.004 & 0.231 \\
\hline MARKETCAP & 6.542 & 0.554 & 447.552 & 0.000 & 27.156 \\
\hline SIZE & 27.084 & 27.040 & 33.735 & 18.682 & 2.282 \\
\hline
\end{tabular}

\subsection{Regression results and discussion}

Table 2 presents the regression results to examine the impact of deferred tax and large accruals on the relationship between earnings (E) and firm value $(\mathrm{Q})$. Model 1 is a basic model without interaction variables, Model 2 adds interaction variables to the base model, and Model 3 adds control variables to Model 2. All three models show that the F-Statistic value is significant at the 1 percent level. The fit of the regression model is significantly improved compared to the fit of the intercept model only. These results specify that the independent variables in the regression model simultaneously influence the firm's dependent variable. R-squared and Adjusted R-squared values increase with the addition of interaction variables and control variables into the regression model. The deferred tax and accrual variables of each company generally change (positive or negative) each year. This indicates that the research data is more cross sectional. Therefore, this study uses research data as pooled data with cross-sectional analysis.

The regression results in Table 2 show that the coefficient of earnings (E) is positive and significant at the 1 percent level indicating the higher the earnings the higher the firm value $(Q)$. The $L P D T \times L P A$ variable has a significant negative coefficient at the 1 percent level. This shows that the firm value $(Q)$ for companies with large positive deferred taxes accompanied by large positive accruals is lower than the firm value $(Q)$ for companies other than those that have large positive deferred taxes accompanied by large positive accruals. Unlike these results, the $L N D T \times L N A$ variable is not significant for all three regression models which means that the firm value $(Q)$ for companies with large negative deferred taxes accompanied by large negative accruals is not different from the firm value $(Q)$ for the companies other than those with large negative deferred taxes which are accompanied by large negative accruals.

$L P D T \times L P A \times E$ and $L N D T \times L N A \times E$ interaction variables are the main variables of this study. The $L P D T \times$ $L P A \times E$ coefficient for Model 2 and Model 3 is negative significant at the 1 percent level indicating the association between earnings $(E)$ and firm value $(Q)$ for companies that report large positive deferred taxes with large positive accruals is lower compared to that for companies other than those reporting large positive deferred taxes with large positive accruals. In other words, a large positive deferred with large positive accruals weaken the relationship between earnings and firm value.

The $D A R$ control variable has a significant negative coefficient at the 5 percent level which means that companies with high debt financing tend to have low firm value. Conversely, companies with low debt financing tend to have high firm value. The SIZE variable with a significant positive coefficient at the 1 percent level specifies that the larger the company the higher the firm value. S1 through S8 are industrial sector control variables. Each industrial sector has a significant negative coefficient at the level of 1 percent. These results show that the firm value for companies in the industrial sector 1 to 9 has a lower firm value compared to that in sector 9 .

Table 3. Regression results of the impact of large deferred taxes and large accruals on the relationship between earnings $(E)$ and firm value $(Q)$

\begin{tabular}{|l|c|c|c|c|c|c|}
\hline$E$ & 8.33 & 0.00 & 8.99 & 0.00 & 6.92 & 0.00 \\
\hline $\begin{array}{l}\text { LPDT } \\
L P A\end{array}$ & -4.93 & 0.00 & 0.36 & 0.00 & 0.30 & 0.00 \\
\hline $\begin{array}{l}\text { LNDT } \\
L N A\end{array}$ & 0.56 & 0.58 & -0.07 & 0.61 & -0.07 & 0.61 \\
\hline $\begin{array}{l}\text { LPDT } \\
\text { LPA } \times E\end{array}$ & & & -6.92 & 0.00 & -5.37 & 0.00 \\
\hline $\begin{array}{l}\text { LNT } \times \\
\text { LNA } \times E\end{array}$ & & & 0.81 & 0.54 & 0.14 & 0.91 \\
\hline$D A R$ & & & & & -0.26 & 0.02 \\
\hline$S I Z E$ & & & & & 0.18 & 0.00 \\
\hline$S 1$ & & & & & -0.39 & 0.00 \\
\hline$S 2$ & & & & & -0.45 & 0.00 \\
\hline$S 3$ & & & & -0.54 & 0.00 \\
\hline$S 4$ & & & & -0.48 & 0.00 \\
\hline$S 5$ & & & & -0.35 & 0.00 \\
\hline$S 6$ & & & & & 0.00 \\
\hline
\end{tabular}


End of Table 3

\begin{tabular}{|l|c|c|c|c|c|c|}
\hline \multirow{2}{*}{ Variable } & \multicolumn{2}{|c|}{ Model (1) } & \multicolumn{2}{c|}{ Model (2) } & \multicolumn{2}{c|}{ Model (3) } \\
\cline { 2 - 7 } & Coef. & Prob. & Coef. & Prob. & Coef. & Prob. \\
\hline$S 7$ & & & & & -0.38 & 0.00 \\
\hline$S 8$ & & & & & -0.42 & 0.00 \\
\hline$C$ & 0.91 & 0.00 & 0.83 & 0.00 & -3.42 & 0.00 \\
\hline$N$ & 1938 & & 1938 & & 1938 & \\
\hline R-squared & 0.22 & & 0.23 & & 0.30 & \\
\hline $\begin{array}{l}\text { Adjusted } \\
\text { R-squared }\end{array}$ & 0.21 & & 0.22 & & 0.29 & \\
\hline F-statistic & 44.80 & & 40.32 & & 54.15 & \\
\hline $\begin{array}{l}\text { Prob } \\
\text { (F-statistic) }\end{array}$ & 0.00 & & 0.00 & & 0.00 & \\
\hline
\end{tabular}

The results of the regression analysis show that the coefficient of the $L P D T \times L P A \times E$ interaction variable is negative and significant, which means that a large positive deferred tax with a large positive accrual weakens the association between earnings and firm value. Positive deferred taxes which add to the current tax increase net tax, which also means that pre-tax profit is greater than taxable profit. When positive deferred taxes are large, reported earnings can be presented "above normal". Likewise, positive accruals are a component of non-cash earnings which makes profits greater than operating cash flows. Large positive accruals also result in earnings reported in the income statement being presented "above normal". Earnings information above normal means that the quality of earnings is reduced. For these reasons, large positive deferred taxes and large positive accruals weaken the association between earnings and firm value.

Large negative deferred taxes and large negative accruals should also have reduced earnings quality. However, the results of the regression analysis show that large negative deferred taxes with large negative accruals do not affect the relationship between earnings and firm value. Possible explanations are as follows. First, that "abnormal" earnings, in this case, "below normal earnings", imply relatively low earnings quality. Low earnings quality can be a negative signal for the company's future performance. However, the "below normal" earnings are reported based on "conservative" accounting policies which can be a positive signal due to their prudential nature. Besides, a large negative deferred tax with a large negative accrual can have different implications from a negative deferred tax accompanied by a negative accrual that is too large. These opposing properties may result in large negative deferred taxes with large negative accruals not affecting the association between earnings and the value of the company.

The results of this study are generally following the findings of previous studies although there are differences in the measurement of variables including the grouping of observations in this study based on large deferred taxes (either positive or negative) versus small deferred taxes accompanied by large accruals (either positive or negative) versus small accruals. The results of this study, particularly for positive deferred taxes, are consistent with the findings of (Adiati et al., 2018) which show that deferred taxes have weakened the relationship of earnings with stock returns. This result confirms the role of deferred tax in stock valuation or company valuation based on earnings information. Regarding deferred tax, these results are also consistent with the findings of Blaylock et al. (2012) who found that change in pretax book income had a negative effect on returns for large positive book-tax differences.

The findings of this study, particularly concerning accruals, are also in line with the results of Akbar et al. (2011) study which found that the cash component of earnings contained incremental information content compared to accrual components. In the case of large positive accruals, the findings of this study are similar to those of Callao et al. (2016) which show that the relevance of earnings is low for firms with high discretionary accrual intensities.

The results relating to large negative deferred taxes accompanied by large negative accruals are not as predicted. This can be caused by the method of grouping accruals into large accruals or small accruals. The findings of Kousenidis et al. (2009) show that conservatism increases the relevance of earnings but that excessive conservatism results in a decrease in the relevance of earnings. Sutopo and Hananto (2019) also found that the more extreme negative accrual groups weakened the relationship between earnings and firm value.

\section{Conclusions}

This study aims to examine the impact of large deferred taxes with large accruals on the relationship between earnings and firm value. The first main findings show that a large positive deferred tax with large positive accruals has a positive impact on the association between earnings and firm value. This is due to both large positive deferred taxes and large positive accruals having the nature of increasing reported earnings. Large positive deferred taxes with large positive accruals result in earnings reported being "above normal". However, the second findings of this study show a large negative deferred tax with large negative accruals do not have an impact on the association between earnings and firm value. Both large negative deferred tax and large negative accruals have the nature of decreasing reported earnings. Large negative deferred taxes with large negative accruals result in earnings reported being "below normal" caused by conservative accounting policies. The impact of conservative accounting on the association between earnings and firm value may be influenced by positive versus negative perceptions by the market, as well as being influenced by the magnitude of the conservatism.

The results of this study suggest the role of large deferred taxes and large accruals in the valuation of companies based on profits for management and investors. 
More specifically, if the company reports a large positive deferred tax that is accompanied by a large positive accrual, the effect of earnings on the value of the company will decrease. However, the effect of earnings on firm value for companies that report large negative deferred taxes and large negative accruals is not different from that for companies that report small negative deferred taxes and small negative accruals.

\section{Limitation and future research}

This paper has limitations, including the selection of observations of companies that have positive equity and presenting deferred tax in the income statement. Companies with negative equity were excluded from the sample due to bias in measuring company value with Tobin's $Q$. Deferred tax which is presented in the income statement accompanied by its disclosure in the notes to the financial statements has a higher value relevance compared to deferred tax which is disclosed in the notes to financial statements only. However, this limitation of the sample reduces the generalizability of the study results. Future studies could include firms with negative equity consequently using dependent variables that do not require equity data, such as stock returns. Besides, companies that disclose deferred taxes in notes to financial statement only (and do not present them in the income statement) can also be included in the sample by adding research objectives. Another limitation is the grouping of company observations into large (small) deferred tax and accruals using the median as the cutoff. The use of this median follows previous studies, as described above. Future studies may use other large (small) groupings with different research objectives, for example, the top (bottom) quintile to examine the role of deferred tax and large (small) accruals.

\section{Funding}

The authors gratefully acknowledge the funding support from Universitas Sebelas Maret for this research.

\section{References}

Adegboye, A., Ojeka, S., Adegboye, K., Ebuzor, E., \& Samson, D. (2019). Firm performance and condensed corporate governance mechanism: Evidence of Nigerian financial institutions. Business: Theory and Practice, 20, 403-416. https://doi.org/10.3846/btp.2019.38

Adiati, A. K., Rahmawati, \& Bandi. (2018). Does disclosure method of deferred tax matter for investors in stock valuation based on earnings? International Journal of Business and Society, 19, 676-688.

Akbar, S., Shah, S. Z. A., \& Stark, A. W. (2011). The value relevance of cash flows, current accruals, and non-current accruals in the UK. International Review of Financial Analysis, 20(5), 311-319. https://doi.org/10.1016/j.irfa.2011.06.005

Bauman, M. P., \& Shaw, K. W. (2016). Balance sheet classification and the valuation of deferred taxes. Research in Accounting Regulation, 28(2), 77-85.

https://doi.org/10.1016/j.racreg.2016.09.004
Blaylock, B., Shevlin, T., \& Wilson, R. J. (2012). Tax avoidance, large positive temporary book-tax differences, and earnings persistence. The Accounting Review, 87(1), 91-120.

https://doi.org/10.2308/accr-10158

Buchanan, B., Cao, C. X., \& Chen, C. (2018). Corporate social responsibility, firm value, and influential institutional ownership. Journal of Corporate Finance, 52, 73-95. https://doi.org/10.1016/j.jcorpfin.2018.07.004

Callao, S., Cimini, R., \& Jarne, J. I. (2016). Value relevance of accounting figures in presence of earnings management. Are enforcement and ownership diffusion really enough? Journal of Business Economics and Management, 17(6), 1286-1299. https://doi.org/10.3846/16111699.2016.1203816

Chang, L. L., Hsiao, F. D., \& Tsai, Y. C. (2013). Earnings, institutional investors, tax avoidance, and firm value: Evidence from Taiwan. Journal of International Accounting, Auditing and Taxation, 22(2), 98-108.

https://doi.org/10.1016/j.intaccaudtax.2013.07.001

Chen, A., \& Gong, J. J. (2019). Accounting comparability, financial reporting quality, and the pricing of accruals. Advances in Accounting, 45. https://doi.org/10.1016/j.adiac.2019.03.003

Eyring, H., \& Narayanan, V. G. (2018). Performance effects of setting a high reference point for peer-performance comparison. Journal of Accounting Research, 56(2), 581-615. https://doi.org/10.1111/1475-679X.12199

Farooq, O., Bakhadirov, M., \& Ahmed, N. (2020). Geographic variation in religiosity and its impact of dividend policies. Asian Academy of Management Journal of Accounting and Finance, 16(1), 109-125. https://doi.org/10.21315/aamjaf2020.16.1.6

Hanlon, D., Navissi, F., \& Soepriyanto, G. (2014). The value relevance of deferred tax attributed to asset revaluations. Journal of Contemporary Accounting and Economics, 10(2), 87-99. https://doi.org/10.1016/j.jcae.2014.03.001

Hanlon, M., \& Shevlin, T. (2005). Book-tax conformity for corporation income: an introduction to the issues. Tax Policy and the Economy, 19, 101-134.

https://doi.org/10.1086/tpe.19.20061897

Hossain, A., \& Nguyen, D. (2016). Capital structure, firm performance and the recent financial crisis. Journal of Accounting and Finance, 16(1), 76-89.

Kantšukov, M., \& Sander, P. (2018). A lesson in valuation from Estonia: The difference between the fundamental value of equity under distributed and traditional profit taxation systems. Business: Theory and Practice, 19, 146-156. https://doi.org/10.3846/btp.2018.15

Kasipillai, J., \& Mahenthiran, S. (2013). Deferred taxes, earnings management, and corporate governance: Malaysian evidence. Journal of Contemporary Accounting and Economics, 9(1), 1-18. https://doi.org/10.1016/j.jcae.2013.03.001

Khaoula, F., \& Moez, D. (2019). The moderating effect of the board of directors on firm value and tax planning: Evidence from European listed firms. Borsa Istanbul Review, 19(4), 331-343. https://doi.org/10.1016/j.bir.2019.07.005

Kousenidis, D. V., Ladas, A. C., \& Negakis, C. I. (2009). Value relevance of conservative and non-conservative accounting information. International Journal of Accounting, 44(3), 219238. https://doi.org/10.1016/j.intacc.2009.06.006

Lee, N. (2019). R \& D accounting treatment, firm performance, and market value: Biotech firms case study. Journal of International Studies, 12(2), 66-81.

https://doi.org/10.14254/2071-8330.2019/12-2/4

Lewellen, J., \& Resutek, R. J. (2019). Why do accruals predict earnings? Journal of Accounting and Economics, 67(2-3), 336356. https://doi.org/10.1016/j.jacceco.2018.12.003 
Li, V. (2019). The effect of real earnings management on the persistence and informativeness of earnings. The British Accounting Review, 51, 402-423.

https://doi.org/10.1016/j.bar.2019.02.005

Loh, L., Thomas, T., \& Wang, Y. (2017). Sustainability reporting and firm value: Evidence from Singapore-listed companies. Sustainability (Switzerland), 9(11), 1-12. https://doi.org/10.3390/su9112112

Martins, M. M., \& Lopes, I. T. (2016). Intellectual capital and profitability: A firm value approach in the European companies. Business: Theory and Practice, 17(3), 234-242. https://doi.org/10.3846/btp.2016.673

Mbugua, C. M., Oluoch, J. O., \& Ndambiri, A. N. (2018). Determinants of firm value of securities for companies that had issued initial public offering. The Strategic Journal of Business \& Change Management, 5(2), 769-787.

Moreira, J. C. C., Lima, G. A. S. F., \& Góis, A. D. (2019). Effects of institutional factors on the accruals anomaly in Latin America. Journal of International Accounting, Auditing and Taxation, 36. https://doi.org/10.1016/j.intaccaudtax.2019.100269

Nazir, M. S., \& Afza, T. (2018). Does managerial behavior of managing earnings mitigate the relationship between corporate governance and firm value? Evidence from an emerging market. Future Business Journal, 4(1), 139-156.

https://doi.org/10.1016/j.fbj.2018.03.001

Ni, Y., Huang, P., Chiang, P., \& Liao, Y. (2019). Cash flow statements and firm value: Evidence from Taiwan. Quarterly Review of Economics and Finance, 71, 280-290.

https://doi.org/10.1016/j.qref.2018.09.004

Osazuwa, N. P., \& Che-ahmad, A. (2016). The moderating effect of profitability and leverage on the relationship between ecoefficiency and firm value in publicly traded Malaysian firms. Social Responsibility Journal, 12(2), 295-306. https://doi.org/10.1108/SRJ-03-2015-0034

Penman, S. H. (2013). Financial statement analysis and security valuation (5h ed.). McGraw-Hill.

Phillips, J., \& Pincus, M. (2003). Earning management: New evidence based on deferred tax expense. The Accounting Review, 78(2), 492-521. https://doi.org/10.2308/accr.2003.78.2.491

Prabowo, R., Hooghiemstra, R., \& Van Veen-Dirks, P. (2018). State ownership, socio-political factors, and labor cost stickiness. European Accounting Review, 27(4), 771-796.

https://doi.org/10.1080/09638180.2017.1329659
Qu, X., \& Zhang, G. (2015). Value-relevance of earnings and book value over the institutional transition in China: The suitability of fair value accounting in this emerging market. International Journal of Accounting, 50(2), 195-223. https://doi.org/10.1016/j.intacc.2013.01.009

Samara, A. D. (2014). Assessing the relevance of deferred tax items: Evidence from loss firms during the financial crisis. The Journal of Economic Asymmetries, 11, 138-145. https://doi.org/10.1016/j.jeca.2014.09.003

Scott, W. R. (2015). Financial accounting theory (7th ed.). Pearson Canada Inc.

Shan, Y. G. (2015). Value relevance, earnings management and corporate governance in China. Emerging Markets Review, 23, 186-207. https://doi.org/10.1016/j.ememar.2015.04.009

Sloan, R. G. (1996). Do stock prices fully reflect information in accruals and cash flows about future earnings. The Accounting Review, 71(3), 289-315.

Spence, M. (1973). Job market signaling. The Quarterly Journal of Economics, 87(3), 355-374. https://doi.org/10.2307/1882010

Sutopo, B., \& Hananto, S. T. (2019). Profitability and firm value: the impact of non-cash value flow recorded in the financial statements. International Journal of Economic Policy in Emerging Economies, 12(5), 490-502.

https://doi.org/10.1504/IJEPEE.2019.104640

Tang, T. Y. H., \& Firth, M. (2012). Earnings persistence and stock market reactions to the different information in book-tax differences: evidence from China. International Journal of Accounting, 47(3), 369-397. https://doi.org/10.1016/j.intacc.2012.07.004

Tikk, J. (2010). Accounting changes in the public sector in Estonia. Business: Theory and Practice, 11(1), 77-85. https://doi.org/10.3846/btp.2010.09

Wang, L. (2019). Do investors care about earnings quality? The case of Chinese reverse mergers. Pacific Basin Finance Journal, 55(February), 82-94.

https://doi.org/10.1016/j.pacfin.2019.02.008 